\title{
ANALISIS DINAMIS PERMINTAAN DAN PENAWARAN KOMODITAS KEDELAI DI JAWA TIMUR
}

\author{
Muhammad Rifa'i \\ Fakultas Ekonomi Unv. Tribhuwana Tunggadewi Malang \\ Jl. Telaga Warna Blok C Tlogomas Malang (0341) 565500 \\ Email: rifaidr@gmail.com
}

\begin{abstract}
The aims of this research are: (a) analyze factors influenceing supllay, import and demand of soybean in east java region; (b) analyze factors influencing price of soybean; (c) analyze linkage among suplay, import, demand and domistic price of soyben simultaneously. This research conducted in east java as main producer of soyben in Indonesia. We use secondary data for 1980-2004 periods wits simutaneus models, especially two stage least square method. The result of research shows that the model of demand and supply used had fulfilling economic, statistic and econometric criteria so can be used to explain economic behavior of soyben in east java correctly. Suplay of soybean influenced positively by corn price, productivity and harvesting are of soybean commodity, while domistic price of soybean, price of rice, price of fertilizer, world price and so lags of supplay does not significant. Import positively influenced by income and current demand, and negatively import does not significant. Domistic demand of soybean positively influenced by population size and negatively influenced influenced by per capita income, while other variables such as domistic price, corn price and previous demand does not significant. Domistic price positively influenced by suplay and exchange rate, and so previosly domistic price, while demand and world price does not signficant.
\end{abstract}

Key words: demand of soybean, supplay of soybean, price of soybean.

Secara umum peran sekor pertanian dalam pembangunan nasional adalah menyediakan bahan pangan bagi pendudukan, menciptakan lapangan pekerjaan dan menyediakan bahan baku bagi sector industry, pembentukan modal investasi dan menghasilkan devisa melalui kegiatan ekspor hasil pertanian. Peranaan tersebut cukup menonjol selama 25 tahun terakhir(Adnyana dan Manwan, 1999).

Pemenuhan kebutuhan pangan yang cukup bagi penduduk merupakan bagian integral dari pembangunan nasional. Pertumbuhan penduduk yang masih cukup tinggi, pendapatan per capita makin meningkat, dan pola konsumsi masyarakat serta globalisasi situasi pangan dunia menuntut penyediaan pangan semakin meningkat. Di 
lain pihak persediaan pangan di pasar dunia berfluktuasi dengan harga yang tidak menentu dan sangat di pengaruhi oleh stabilitas produksi di Negara pemasok. Adalah suatu keputusan yang tepat bahwa pemerintah berupaya memenuhi kebutuhan pangan dengan lebih mengandalkan kemampuan produksi dalam negeri sekalipun tidak menutup kemungkinan mengimpor dalam jumlah terbatas apabila mengalami gangguan dalam penyediaan pangan nasional.

Untuk meningkatkan produksi pangan, pemerintah telah melakukan bagian upaya dan mengalokasikan dana yan cukup besar untuk menaikkan produksi dalam negeri. Hal ini tercermin dari pembangunan irigasi, penelitian dan pengembangan teknologi, subsidi pupuk dan pestisida, kebijakan harga dan perkreditan serta pembinaan dan penyuluhan (Kasyno, 1998). peningkatan pangan terutama dimaksudkan untuk penyediaan pangan yang mempunyai arti penting dalam mempertinggi taraf hidup, kecerdasan dan kesejahteraan masyarakat. Peningkatan jumlah penduduk dan ragam kebutuhan bahan pangan, baik untuk konsumsi langsung maupun untuk produk olahan yang pada akhirnya akan meningkatkan kebutuhan bahan baku industri.

Kedelai merupakan salah satu tanaman pangan yang menduduki posisi penting setelah padi karena merupakan komoditas yang memiliki nilai ekonomi yang strategis dan potensi pengembanganya cukup besar. Selain sebagai bahan makanan, kedelai mengandung protein nabati yang tinggi, sumber lemak, vitamin, dan mineral sehingga mampu memperbaiki keadaan gizi masyarakat. Dengan peranan yang demikian menyebabkan permintaan kedelai terus mengalami peningkatan ( Rukmana, 1997).

Pertumbuhan permintaan kedelai cukup pesat terjadi selama beberapa tahun terakhir terutama untuk konsumsi rumah tangga, bahan baku industri seperti tahu, tempe, tauco, kecap serta meningkatnya permintaan terhadap pakan ternak sebagai akibat berkembanganya industri perunggasan. Tingkat permintaan kedelai terhadap komoditas kedelai terus mengalami peningkatan. Dari tahun 1986-1986, tingkat konsumsi per kapita per tahun sebesar $8,80 \mathrm{~kg}$, kemudian meningkat menjadi $\mathrm{xx}, \mathrm{xx}$ pada tahun 1995. Artinya terjadi pertumbuhan permintaan yang pesat baik untuk konsumsi maupun kebutuhan pakan ternak. Namun pada sisi lain, laju pertumbuhan 
produksi kedelai dalam negeri belum mampu memenuhi permintaan pasar. Akibatnya kesenjangan produksi dan konsumsi semakin melebar sehingga harus ditutup dengan impor ( Amang, 1997)

Volume impor kedelai dari tahun ke tahun mengalami kenaikan sebagai akibat penyediaan dalam negeri yang tidak sebanding dengan kenaikan permintaan. Pada tahun 1993 , jumlah volume kedelai impor sebesar 390.904 ton, pada tahun 1995 naik menjadi 473.250 ton dan mencapai sekitar 600.000 ton pada tahun 1996. Pada sisi lain total permintaan kedelai di perkirakan meningkat sekitar 3,00 juta ton pada tahun 2003, sementara pada tahun 2010 diperkirakan akan menjadi 2,80 ton dengan tingkat pertumbuhan 4-5\% tahun ( BULOG, 1999).

Berdasar data, kecendrungan volume penyediaan dalam negeri. Oleh karena itu apabila tidak ada usaha peningakatan produksi dengan memanfaatkan potensi sumber daya yang tersedia maka volume impor akan terus berkembang. Sampai saat ini, produksi utama komoditi kedelai di Indonesia adalah Pulau Jawa karena memproduksi $61 \%$ dari total produsi kedelai nasional. Menurut besarnya kontribusi terhadap kedelai nasional, contributor produksi utama kedelai adalah Jawa Timur mencapai 28\% diikuti Jawa Tengah sebesar 15\% dan sisanya daerah lain sebesar $8 \%$. Sementara kontribusi daerah produksi di luar Jawa mencapai 39 \% dari total produksi kedelai nasional. Jawa Timur, meskipun merupakan daerah penghasilan utama kedelai nasional, namun selama periode 1996-2001, luas panennya cenderung menurun. Selama kurun waktu tersebut tercatat hanya pada tahun 1999 luas panen kedelai Jawa Timur mengalami kenaikan, yakni sebesar 401.809 ha untuk selanjutnya menurun kembali pada tiga tahun terakhir (9000-2002).

Aspek produksi, dalam kurun waktu 1996-2001 jumlah produksi sangat berfluktuasi dengan jumlah tertinggi di capai pada tahun 1997, untuk selanjutnya mengalami penurunan. Khusus untuk tahun 2000, kondisi perkedelaian nasional sangat tidak di untungkan karena adanya kedelai impor yang harganya lebih murah dibanding dengan harga kedelai produksi domestic sehingga telah menyebabkan jumlah produksi dihasilkan yang tidak sesuai dengan pendapatan yang diterima. Akibat minat petani terhadap komoditas kedelai menurun drastis, petani hanya 
menanam kedelai sekedar melanjutkan kebiasaan pola tanam. hal ini disinyalir oleh DIPERTA (2000) sebagai penyebab utama menurunya luas areal.

Di tinjau menurut wilayahnya, pada tahun 2001 daerah penghasilan utama kedelai Jawa Timur adalah Kabupaten Banyuwangi dengan tingkat produksi 51,30 ribu ton, diikuti oleh Kabupaten Pasuruan ( produksi 43,00 ribu ton), Kabupaten Ngawi (produksi 25,70 ribu ton) dan Kabupaten Ponorogo dengan produksi 25,50 ribu ton. Rataan produktiviatas kedelai pada ke-empat daerah tersebut lebih besar dari rataan produktivitas Jawa Timur. Kabupaten Banyuwangi misalnya, tingkat produktivitas mencapai $14 \mathrm{kw} /$ ha sedangkan rataan produktivitas Jawa Timur hanya sebesar $12 \mathrm{kw} / \mathrm{ha}$. Isamping produktivitas yang di atas rataan Jawa Timur, luas panen npada ke-empat daerah sentral tersebut lebih besar dibanding daerah lain merupakan factor pendorong tingginya jumlah produksi yang di hasilkan.

\section{TINJAUAN PUSTAKA}

\section{Teori permintaan}

Permintaan tehadap suatu barang adalah jumlah barang yang dibutuhkan dan dibeli konsumen pada berbagai tingkat harga. Sedangkan menurut Sudarsono (1995) permintaan menurut pengertian sehari-hari di artikan sebagai jumlah barang yang dibutuhkan( permintaan potensial). Marshall dlam membahas permintaan menggunakan anggapan pendaptan tetap, yaitu mencari pengaruh harga terhadap jumlah barang yang diminta. Dalam pola pemikiran ini yang dimaksud dengan permintaan adalah bebagai kuantitas barang yang diminta pada berbagai tingkat harga. Secara grafis, skala pada sumbu ordinat ( vertical) mengukur harga, sedangkan skala sumbu absis (horizontal) mengukur kuantitas barang.

\section{Teori penawaran}

Penawaran adalah jumlah barang yang ditawarkan oleh penjual atau produsen ke pasar pada berbagai tingkat harga. Suherman ( 1984) mendefinisikan penawaran adalah daftar, grafik atau persamaan yang menunjukkan suatu barang dimana produsen ingin dan dapat menjuak pada berbagai tingkat harga dalam suatu pasar, pada periode waktu tertentu. Menurut Semoen (1992), jumlah barang yang 
ditawarkan tergantung dari beberapa factor-Factor lain yang dapat mempengaruhi jumlah barang yang ditawarkan, selain harga, tidak di jelaskan dan tidak digambarkan dalam kirva penawaran. Kaitannya dengan hal tersebut di atas, maka pergerakan kurva penawaran dapat dapat dibedakan menjadi dua (Miller dan Meiners, 1993); pertama, gerakan sepanjang kurva penawaran itu sendiri ( movement along supply curve) dan yang kedua, merupakan pergeseran kurva penawaran ( shift in the supply curve). Fungsi penawaran suatu barang atau produk adalah menunjukkan hubungan antara jumlah produksi atau jumlah produk yang di jual disesuaikan dengan perubahan harga (semaoen, 1992).

\section{FaKtor determinasi permintaan}

a. Harga barang itu sendiri

Sesuai dengan hukum permintaan jumlah barang yang diminta berubah secara berlawanan sesuai dengan perubahan harga. Cara lain itu mengekpresiak prisip ini adalah kurva permintaan mempunyai nilai kemiringan negative. Perubahan harga secara nominal menyebabkan pergerakan sepanjang fungsi permintaan tertentu dan pergerakan tersebut ditunjukan oleh perubahan jumlah yang diminta secara berlawanan.

\section{b. Penghasilan (dalam arti uang) konsumen}

Faktor ini pendapatan merupakan factor penentu yang penting dalam permintaan suatu barang. Pada umumnya, semakin besar penghasilan semakin besar pula permintaan.

\section{c. Harga barang lain yang berkaitan}

Barang-barang konsumsi pada umummya mempunyai kaitan penggunaan antara satu dengan yang lain. Kaitan penggunaan antara dua barang konsumsi pada dasarnya dapat dibedakan menjadi 3 macam yaitu: saling mengganti (substitusi), saling melengkapi (komplementer) dan barang material.

\section{d. Jumlah penduduk}


pertambahan penduduk yang diikuti dengan perkembangan kesempatan kerja menyebabkan banyak orang menerima pendapatan dan hal ini menambah daya beli masyarakat.

\section{Faktor-faktor determinasi penawaran}

Penawaran diartikan sebagai jumlah barang yang diproduksi dan dijual produsen ( Samuelson dan Nordhaus, 1997). Determinasi penawaran dipengaruhi oleh beberapa factor antara lain: harga barang itu sendiri, Barang lain yang berkaitan, harga factor produksi dan tingkat teknologi.

\section{Elastisitas permintaan dan penawaran}

Salah satu karekteristik penting dari kurva atau fungsi permintaan pasar adalah derajat kepekaan jumlah permintaan terhadap perubahan salah satu factor yang mempengaruhi . ukuran derajat kepekaan ini disebut elastisitas. Koefisien elastisitas permintaan mengukur persentase perubahan variable yang mempengaruhinya. Variable yang mempengaruhi permintaan individu pada dasarnya dapat digolongkan dalam tiga kelompok yaitu harga barang yang diminta, pendapatan dan harga barang lain tertentu.

\section{METODE PENELITIAN}

Penelitian ini merupakan kajian terhadap perilaku variabel ekonomi dari suatu komoditas kedelai dangan menggunakan data runtut waktu pada periode tertentu. Penelitian dilakukan dengan pendekatan model persamaan simultan (simultan equation model) sehingga keterkaitan antara masing-masing variabel ekonomi yang diteliti dapat dijelaskan dengan baik. Model yang dihasilkan digunakan untuk mengevaluasi berbagai skenario kebijakan dan dampaknya terhadap kesejahteraan para pelaku pasar (produsen, konsumen, dan pedagang) serta pihak pemerintah.

Penelitian dilakukan di daerah Jawa Timur karena merupakan penghasil utama kedelai di Indonesia sebesar $28 \%$. Metode pengumpulan data yang dilakukan dalam penelitian ini adalah metode-metode dokumentasi. Dimana dalam metode ini dilakukan pencatatan data dan arsip yang dibutuhkan. Data yang digunakan dalam 
penelitian ini adalah data sekunder selama 24 tahun ( kurun 1980- 2004). Sedangkan Jenis data yang dibutuhkan adalah data yang bersifat kuantitatif yang meliputi: produksi kedelai , harga kedelai, harga beras, harga pupuk, tingkat produktivitas, nilai tukar, harga dunia kedelai, harga jagung dan data lainya.

Untuk mengetahui perilaku faktor yang mempengaruhi permintaan, penawaran, impor dan harga kedelai di Jawa Timur maka di lakukan pendekatan dengan ekonometrik yakni pola khusus model matematik dengan memasukkan peubah pengganggu (error term). Untuk itu dibangun model hipotesis persamaan struktual (structural) atau perilaku (behavioral) yang mempresentasikan fenomena aktual suatu sistem perilaku ekonomi komoditas kedelai.

Secara detail ada empat tahapan dalam kajian yang menggunakn alat analisis ekonometrik, (1) Identifikasi Model, (2) spesifikasi model (maintained hypotesis), (3) Evaluasi parameter, dan (4) evaluasi validitas peramalan model.

\section{Identifikasi Model}

Menurut Intriligator (1978) suatu sistem persamaan dinyatakan teridentifikasi jika dan hanya jika setiap persamaan dari model yang dibangun juga teridentifikasi. Jika satu atau lebih persamaan dari model struktural tidak teridentifikasi, model secara keseluruhan juga menjadi tidak teridentifikasi. Untuk melakukan identifikasi terhadap suatu sistem persamaan dapat dilakukan dengan mencari persamaan reduced form-nya atau dengan menggunkan pendekatan order codition. Namun pendekatan dengan reduced kurang efesien sehingga di gunakan pendekatan order condition (Gujarati, 1995; Koutsiyanis, 1978). Syarat order condition sebagai berikut:

$$
(\mathrm{K}-\mathrm{M}) \geq(\mathrm{G}-1)
$$

Dimana:

$\mathrm{K}=$ total variable dalam model;

M = jumlah variable endogen dan eksogen pada persamaan yang diidentifikasikan kecuali variable lag; 
G = jumlah persamaan dalam model.

$(\mathrm{K}-\mathrm{M})<(\mathrm{G}-1)$, maka persamaan bersifat underindentified,

$(\mathrm{K}-\mathrm{M})=(\mathrm{G}-1)$, maka persamaan bersifat exactlyindentified, dan

( K-M)> ( G-1), maka persamaan bersifat overindentified.

Table 1. hasil identifikasi model berdasarkan order condition

\begin{tabular}{|l|l|l|l|l|l|}
\hline no & Persamaan & M & K-M & G-1 & Identifikasi \\
\hline 1 & Penawaran Kedelai & 8 & $18-8=10$ & 5 & Overidentified \\
2 & Impor Kedelai & 5 & $18-5=13$ & 5 & Overidentified \\
3 & Permintaan Kedelai & 5 & $18-5=13$ & 5 & Overidentified \\
4 & Harga Kedelai & 5 & $18-5=13$ & 5 & Overidentified \\
& Domestik & & & & \\
\hline
\end{tabular}

Metode estimasi yang digunakan dalam penelitian ini adalah metode two stages least squares (2SLS). Selanjutnya pendugaan model di lakukan dengan software SAS/ETS Versi 6.2.

\section{Spesifikasi Model (Maintainen Hypotesis)}

Berdasarkan kajian teoritis dan empirs maka perilaku sistem komoditas kedelai dalam penelitian ini dispesifikasi atas empat persamaan perilaku, masingmasing perilaku penawaran, permintaan, impor dan perilaku harga kedelai domistik.

\section{a. Penawaran kedelai}

Penawaran kedelai diduga dipengaruhi oleh harga dalam negeri dari ouput komoditas bersangkutan, harga output komoditas kompetitor dalam hal penggunaan sumber daya pertanian masing-masing adalah jagung dan padi, tingkat aplikasi teknologi, harga input produksi serta luas panen yang bersangkutan. Sehingga persamaan modelnya adalah sebagai berikut:

$\mathrm{QS}=\mathrm{a}+\mathrm{a}_{1} \mathrm{HKDO}+\mathrm{a}_{2} \mathrm{HJ}+\mathrm{a}_{3} \mathrm{HB}+\mathrm{a}_{4} \mathrm{PROV}+\mathrm{a}_{5} \mathrm{LP}+\mathrm{a}_{6} \mathrm{HPP}+\mathrm{a}_{7} \mathrm{HKD}+\mathrm{a}_{8} \mathrm{QSL}+\mathrm{u}_{1}$ Dimana: 


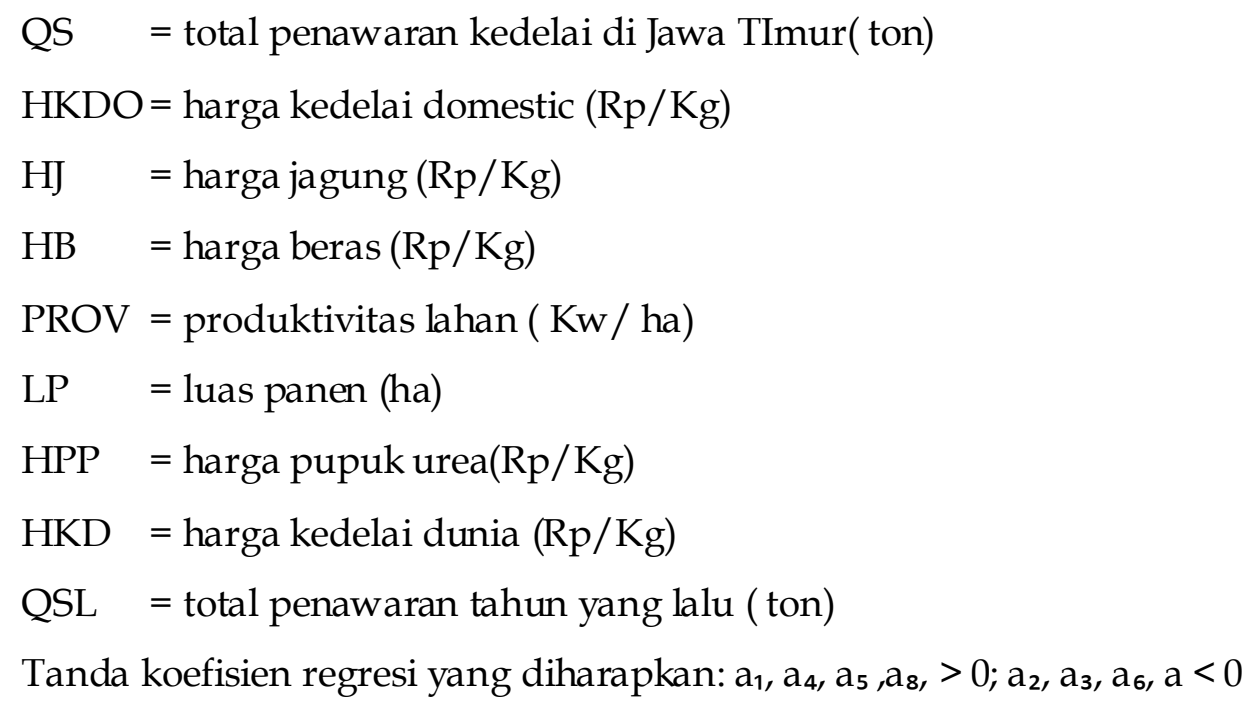

\section{b. Impor Kedelai}

Upaya memenuhi kebutuhan permintaan kedelai tidak hanya dilakukan dengan mengandalkan produksi dalam negeri tetapi juga impor. Dalam penelitian ini faktor yang mempengaruhi perilaku impor dibedakan menjadi dua faktor pendorong yaitu dari dalam negeri yang meliputi permintaan, pendapatan per kapita penduduk, kemapuan produksi dalam negeri, dan impor tahun lalu. Sedangkan dari luar negeri meliputi nilai tukar dan harga kedelai dunia. Sehingga persamaan modelnya adalah sebagai berikut:

$\mathrm{IM}=\mathrm{b}_{0}+\mathrm{b}_{1} \mathrm{YKAP}+\mathrm{b}_{2} \mathrm{PROL}+\mathrm{b}_{3} \mathrm{HKD}+\mathrm{b}_{4} \mathrm{NT}+\mathrm{b}_{5} \mathrm{QD}+\mathrm{b}_{6} \mathrm{IML}+\mathrm{u}_{2}$

Diamana:

$$
\begin{array}{ll}
\mathrm{IM} & =\text { jumlah impor kedelai (ton); } \\
\mathrm{YKAP} & =\text { pendapatan perkapita penduduk (RP/orang); } \\
\mathrm{PROL} & =\text { produksi tahun yang lalu (ton); } \\
\mathrm{NT} & =\text { nilai tukar (RP/\$ US); } \\
\mathrm{QD} & =\text { jumlah permintaan kedelai (ton); } \\
\mathrm{IML} & =\text { jumlah impor kedelai tahun lalu (ton). }
\end{array}
$$

Tanda dugaan koefisien regresi yang diharapkan: $b_{1}, b_{5}, b_{6}>0 ; b_{2}, b_{3}, b_{4},<0$

\section{c. Total Penawaran Kedelai}


Total penawaran agregat suatu komoditas dalam wilayah tertentu merupakan penjumlahan dari seluruh jumlah komonitas, terdiri dari jumlah produksi domistik, jumlah impor dan jumlah stok yang tersedia. Sehingga formulanya dalah sebagai berikut:

$$
\mathrm{QS}=\mathrm{PRO}+\mathrm{IM}+\mathrm{STK}
$$

Dimana:

$$
\begin{aligned}
& \mathrm{PRO}=\text { Jumlah produksi kedelai domestic (ton); } \\
& \text { STOK = jumlah stok kedelai (ton); }
\end{aligned}
$$

Namun mengingat keterbatasan penelitian, data stok yang tersedia tidak diperoleh sehingga stok diasumsikan sama dengan nol, sehingga persamaan ditulis kembali menjadi QS = PRO + IM.

\section{d. Permintaan Kedelai}

Permintaan kedelai terdiri dari komponen permintaan untuk kebutuhan konsumsi rumah tangga, kebutuhan konsumsi pakan, kebutuhan bibit, dan kebutuhan untuk industri berbasis kedelai. Sehingga formulasinya adalah sebagai berikut:

$$
\mathrm{QD}=\mathrm{c}_{0}+\mathrm{c}_{1} \mathrm{HKDO}+\mathrm{c}_{2} \mathrm{HJ}+\mathrm{c}_{3} \mathrm{YKAP}+\mathrm{c}_{4} \mathrm{PDK}+\mathrm{c}_{5} \mathrm{QDL}+\mathrm{u}_{3}
$$

\section{Dimana:}

QD = jumlah permintaan kedelai(ton);

PDK = jumlah penduduk (orang);

QDL = jumlah permintaan kedelai tahun yang lalu (ton).

Tanda koefisien regresi yang diharapkan: $c_{3}, c_{4}, c_{6},>0 ; b_{1}, b_{2}<0$

\section{e. Harga Kedelai Domestic}

Harga kedelai domistik terbentuk dari kekuatan sisi penawaran dan permintaan sehingga variabel penawaran dan permintaan merupakan variabel 
determinan harga. Selain itu juga dipengaruhi harga luar negeri dan nilai tukar rupiah terhadap dolar. Sehaingga persamaannya adalah sebagai berikut:

$\mathrm{HKDO}=\mathrm{d}_{0}+\mathrm{d}_{1} \mathrm{QS}+\mathrm{d}_{2} \mathrm{QD}+\mathrm{d}_{3} \mathrm{HKD}+\mathrm{d}_{4} \mathrm{NT}+\mathrm{d}_{5} \mathrm{HKDOL}+\mathrm{u}_{4}$

Dimana:

NT = nilai tukar ( Rp/US dollar);

HKDOL = harga kedelai domestic tahun lalu $(\mathrm{Rp} / \mathrm{Kg})$.

Tanda koefisien regresi yang diharapkan: $d_{1}, d_{3}, d_{4}, d_{5},>0 ; d_{2}<0$

\section{Keseimbangan Pasar}

Dengan asusmsi bahwa pasar komoditas kedelai adalah pefect competition market, maka market equilibrium terjadi pada saat jumlah permintaan sama dengan penawaran, sehingga keseimbangan pasar dirimuskan sebagai berikut: QD = QS

\section{Pengujian Model}

\section{Pengujian Stationaritas}

$$
\begin{aligned}
\Delta \mathrm{Yt} & =(\rho-1) Y_{t-1}+u_{t} \\
& =\delta Y_{t-1}+u_{t}
\end{aligned}
$$

\section{Uji Autokorelasi}

Untuk mendeteksi autokorelasi diantaranya dapat di lakukan uji Durbin Watson(d). secara matematis, koefisien Durbin Watson diperoleh dari persamaan.

$$
\mathrm{d}=\sum\left(u_{t-} u_{t-1}\right)^{2} / \sum^{u_{t}}
$$

\section{Uji Heteroskedastisitas}

pada penelitian ini uji heteroskedastisitas dilakukan dengan menggunakan metode park. Pengujian dilakukan dengan meregres residual kuadrat() terhadap 
seluruh variable penjelas $\left(x_{i}\right)$ persamaan tertentu. Secara matematis uji park dapat dirumuskan dengan:

$\operatorname{In}\left(u_{i}\right)^{2}=\operatorname{In} \alpha^{2}+\beta \operatorname{InXi}+v_{i}$

\section{Koefisien Determinasi $\left(\mathbf{R}^{2}\right)$}

$\mathrm{R}^{2}=1-\frac{\sum(\hat{\mathrm{Y}}-\bar{Y})^{2}}{\sum(Y i-\bar{Y})^{2}}=1-\frac{\sum e i^{2}}{\sum y_{i}^{2}}$

Dimana:

$\hat{Y} \quad=$ hasil estimasi nilai variable endogen

$\bar{Y} \quad=$ nilai rata-rata variable endrogen

$\mathrm{Y} \quad=$ nilai observasi variable endrogen

$e_{\tilde{i}} \quad=$ nilai disturbance error

$y_{i}^{2}=$ nilai deviasi variable endogen .

\section{HASIL DAN PEMBAHASAN}

Model permintaan dan penawaran kedelai yang di bangun terdiri dari empat persamaan struktual masing-masing persamaan penawaran kedelai(QD), permintaan kedelai(QS), persamaan impor (IM) dan persamaan harga kedelai domestic (HKDO). Keempat persamaan tersebut membentuk sistem persamaan simultan. Mengingat masing-masing persamaan memasukkan variable lag dalam model, sehingga model yang dibangun merupakan sistem persamaan simultan dinamis yang menggunakan data runtut waktu yakni tahun 1981- 2002 dengan jumlah $\mathrm{n}=22$. Model dibangun dari 20 variabel meliputi 4 variabel endogen (endogen variable), 11 variabel penjelas ( exogenous variable) dan 5 variabel lag ( lag endogenous variable). Untuk mencari model terbaik maka dilakukan beberapa kali respesifikasi model. Estimasi pada lampiran merupakan hasil yang dianggap paling memadai untk menjelaskan perilaku permintaan dan penawaran kedelai yang memenuhi beberapa kriteria pemodelan, 
diantaranya adalah kesesuaian hasil estimasi dengan teori ekonomi, kesesuaian secara statistik dan memenuhi kriteria ekonometrik.

\section{Penawaran kedelai}

Table 2 koefisien determinasi cukup tinggi mencapai 0,678, mengungkapkan kemampuan model untuk menjelaskan variasi daripada penawaran kedelai di Jawa Timur cukup tinggi mencapai $67,80 \%$, tingkat produktivitas dan luas areal panen berpengaruh terhadap jumlah penawaran. Setiap kenaikan rataan tingkat produktifitas lahan tanaman kedelai di wilayah poduksi Jawa Timur dalam besaran 1 $\mathrm{kw}$ / ha memberikan dampak pada kenaikan rataan total penawaran kedelai secara keseluruhan pada tahun yang sama di wilayah ini mencapai 343 ton. Peningkatan rataan luas panen kedelai sebesar 1 ha meningkatkan rataan total penawaran kedelai sebesar 0,45 ton. Dengan demikian kebijakan peningkatan intensifikasi pada tingkat petani melalui peningkatan teknologi budidaya di harapkan akan memberikan dampak positif pada peningkatan penawaran kedelai Jawa Timur.

Variabel harga jagung signifikan, namun tanda koefisien estimasi yang di hasilkan tidak sesuai dengan harapan. Kenaikan harga jagung tidak menurunkan tetapi justru sebaliknya meningkatkan total penawaran agregat, jagung bukan merupakan tanaman competitor kedelai.

Table 2 hasil pendugaan parameter penawaran kedelai di Jawa Timur

\begin{tabular}{|c|l|l|l|l|}
\hline Variable & Koef regresi & Std error & t-Hitung & Prob> I t I \\
\hline Intercept & 34457 & 237655 & 0,145 & 0,887 \\
HKDO & $-19,354$ & 157,688 & -0.115 & 0,910 \\
HJ & $390,943^{*}$ & 250,335 & 1,562 & 0,146 \\
HB & $-128,754$ & 130,251 & $-0,989$ & 0,344 \\
PROV & $342,925^{* * *}$ & 135631 & 5,528 & 0,028 \\
LP & $0,448^{* *}$ & 0,223 & 2,000 & 0,070 \\
HPP & $-08,571$ & 152,486 & $-0,528$ & 0,607 \\
HKD & $-24,764$ & 227,969 & $-0,109$ & 0,915 \\
\hline
\end{tabular}




\begin{tabular}{|c|l|l|l|l|}
\hline QSL & 0,199 & 0,305 & 0,652 & 0,527 \\
& & & & \\
\hline $\mathrm{R}^{2}$ & 0,678 & F-hitung & 2,907 & \\
Adj-R ${ }^{2}$ & 0,445 & Prob> F & 0,052 & \\
\hline
\end{tabular}

Keterangan:

$\begin{array}{ll}* & =\text { nyata pada a } 0,20 ; \\ * * & =\text { nyata pada a } 0,10 ; \\ * * * & =\text { nyata pada a } 0,05 ; \\ \text { HKDO } & =\text { harga kedelai domestic; } \\ \text { HJ } & =\text { harga jagung; } \\ \text { HB } & =\text { harga beras; } \\ \text { PROV } & =\text { produktivitas lahan; } \\ \text { LP } & =\text { luas panen; } \\ \text { HPP } & =\text { harga pupuk; } \\ \text { HKD } & =\text { harga kedelai dunia; } \\ \text { QSL } & =\text { penawaran tahun yang lalu. }\end{array}$

Harga beras meskipun parameter regresi yang dihasilkan telah sesuai dengan harapan, namun tidak segnifikan dengan nilai t hitung sangat kecil- 0,989 sehingga padi bukan merupakan komoditas pesaing kedelai dalam penggunaan sumberdaya lahan usaha tani. Harga kedelai domestic dan harga kedelai dunia, walaupun koefisien regresi yang dihasilkan pada kedua variable tersebut sesuai harapan yakni bertanda negative. Namun secara statistic tidak signifikan . Petani kedelai tidak responsive terhadap perubahan harga dari komoditas yang diusahakannya. Sikap petani kedelai yang tidak respon juga terjadi dalam kaitannya dengan harga input yakni pupuk (urea) yang tidak signifikan, maka berapapun penurunan harga pupuk yang terjadi di pasar tidak membuat petani tertarik untuk memperluas areal tanam kedelai sehingga produksi juga tidak mengalami kenaikan, dan akibatnya total penawaran juga tidak terpengaruh. Penawaran tahun lalu yang tidak signifikan, 
penawaran kedelai tahun sekarang tidak dipengaruhi oleh kecendrungan perilaku penawaran pada tahun-tahun sebelumnya.

\section{Impor kedelai}

Tingkat pendapatan per kapita penduduk merupakan factor yang penting dalam mempengaruhi impor kedelai di Jawa Timur, semakin tinggi tingkat pendapatan penduduk memberikan pengaruh positif terhadp impor kedelai.

Table 3 parameter regresi impor kedelai

\begin{tabular}{|l|l|l|l|l|}
\hline variable & Koef regresi & Std error & t-hitung & Prob> I t I \\
\hline Intercept & 361600 & 166638 & 2,170 & 0,049 \\
YKAP & $0,121^{* * *}$ & 0,055 & 2,181 & 0,048 \\
PROL & $-0,925$ & 0,221 & $-4,186$ & 0,001 \\
HKD & $-262,513 \mathrm{~ns}$ & 209.570 & $-1,253$ & 0,232 \\
NT & $-47.338^{* * *}$ & 21.013 & $-2,253$ & 0,042 \\
QD & $0,513^{* *}$ & 0,241 & 2,130 & 0,052 \\
IML & 0.073 & 0,173 & 0,426 & 0,677 \\
& & & & \\
\hline R $^{2}$ & 0,625 & F-hitung & 3,616 & \\
Adj-R & 0,452 & Prob> F & 0,024 & \\
\hline
\end{tabular}

Keterangan:

\begin{tabular}{|c|c|}
\hline * & $=$ nyata pada a 0,20 \\
\hline ** & $=$ nyata pada a 0,10 \\
\hline$* * *$ & $=$ nyata pada a 0,05 \\
\hline$* * * *$ & $=$ nyata pada a 0,$01 ;$ \\
\hline ns & = tidak nyata; \\
\hline YKAP & = pendapatan per kapita; \\
\hline PROL & $=$ produksi tahun yang lalu; \\
\hline NT & = nilai tukar RP/\$ US; \\
\hline
\end{tabular}


$\begin{array}{ll}\text { QD } & =\text { permintaan; } \\ \text { IML } & =\text { impor tahun yang lalu } .\end{array}$

Jumlah produksi kedelai tahun sebelumnya signifikan terhadap jumlah impor. Nilai tukar rupiah terhadap US dollar signifikan mempengaruhi impor, setiap kenaikan jumlah rupiah terhadap US dollar atau dengan kata lain setiap rupiah mengalami depresiasi sebesar Rp 1 terhadap US dollar akan berpengaruh terhadap penurunan jumlah impor kedelai di Jawa Timur cukup besar, mencapai rataan 47,33 ton/ tahun. Permintaan signifikan mempengaruhi impor pada taraf kepercayaan $90 \%$, dapat di pahami mengingat akibat ketidak mampuan produsen kedelai domestic untuk menghasilkan produksi sesuai permintaan, maka kenaikan permintaan kedelai akan mendorong pemerintah maupun pelaku bisnis lain untuk meningkatkan jumlah impor.

\section{Permintaan kedelai}

Variable pendapatan per kapita berpengaruh terhadap permintaan, peningkatan pendapatan tidak meningkatkan permintaan terhadap kedelai tetapi sebaliknya menyebabkan terjadinya penurunan. Jumlah penduduk berpengaruh nyata terhadap permintaan kedelai, setiap peningkatan 100 jiwa penduduk per tahun akan diiringi dengan peningkatan terhadap komoditas kedelai sebesar 8 ton pada tahun yang sama. Harga kedelai domestic dan harga komodititas komplemen (jagung) tidak berpengaruh terhadap permintaan. Demkian juga dengan variable permintaan tahun yang lalu.

Table 4 parameter regresi permintaan kedelai.

\begin{tabular}{|l|l|l|l|l|}
\hline variable & Koef regresi & Std error & t-hitung & Prob> I t I \\
\hline Intercept & -1588022 & 845702 & -1.878 & 0,081 \\
HKDO & $116,573 \mathrm{~ns}$ & 126,860 & 0,919 & 0,373 \\
HJ & $-170,246 \mathrm{~ns}$ & 168.097 & $-1,013$ & 0,328 \\
YKAP & $-0,102^{*}$ & 0,067 & $-1,519$ & 0,151 \\
PDK & $0,080^{* * *}$ & 0,033 & 2,385 & 0,031 \\
\hline
\end{tabular}




\begin{tabular}{|l|l|l|l|l|}
\hline QDL & $-0,220 \mathrm{~ns}$ & 0,377 & $-0,584$ & 0,568 \\
\hline $\mathrm{R}^{2}$ & 0,573 & F-hitung & 3,759 & \\
Adj-R & 0,420 & Prob> F & 0,022 & \\
\hline
\end{tabular}

Keterangan:

* $\quad=$ nyata pada a 0,02 ;

$* * * \quad=$ nyata pada $\alpha 0,05$;

ns = tidak nyata;

PDK = produksi tahun yang lalu dan QDL = permintaan yang lalu.

\section{Harga kedelai domestik}

Variable penawaran kedelai berpengaruh nyata terhadap harga kedelai domestik, terdapat pengaruh positif dari jumlah penawaran terhadap harga keseimbangan pada pasar kedelai domestic. Nilai tukar signifikan mempengaruhi perilaku harga kedelai domestic, makin tinggi nilai tukar rupiah terhadap US dollar memberikan pengaruh terhadap peningkatan harga kedelai yang semakin tinggi. Harga kedelai domestic tahun sebelumnya juga turut berpengaruh terhadap pembentukan harga pada tahun sekarang, artinya terdapat pengaruh secara positif antara trend harga kedelai domestic tahun lalu dengan harga pada tahun sesudahnya. Permintaan dan harga kedelai dunia tidak signifikan, menjelaskan bahwa teori pemintaan tidak berlaku dan fluktuasi harga domestic tidak terpengaruh oleh perubahan harga kedelai dunia.

Tabel 5. parameter regresi Harga kedelai domistik

\begin{tabular}{|l|l|l|l|l|}
\hline variable & Koef regresi & Std error & t-hitung & Prob> I t I \\
\hline Intercept & $-838,035$ & 618,904 & $-1,354$ & 0,197 \\
QS & $0,0028^{*}$ & 0,002 & 1,408 & 0,180 \\
QD & $-0,0013 \mathrm{~ns}$ & 0,001 & $-0,734$ & 0,474 \\
HKD & $-0,1641 \mathrm{~ns}$ & 0,708 & $-0,231$ & 0,820 \\
NT & $0,2086^{* * * *}$ & 0,066 & 3,124 & 0,007 \\
HKDOL & $0,3537^{*}$ & 0,241 & 1,462 & 0,165 \\
\hline R $^{2}$ & & F-hitung & 41,813 & \\
\hline
\end{tabular}




\begin{tabular}{|l|l|l|l|l|}
\hline Adj-R & & Prob> F & 0,0001 & \\
\hline
\end{tabular}

Keterangan:

$\begin{array}{ll}* & =\text { nyata pada a } 0,02 ; \\ * * * * & =\text { nyata pada a } 0,01 ; \\ \text { ns } & =\text { tidak nyata; } \\ \text { HKDOL } & =\text { hrga kedelai domestic thun yang lalu. }\end{array}$

\section{Keterkaitan perilaku permintaan dan penawaran}

Berdasarkan hasil analisis maka dapat dibangun model keterkaitan antara empat persamaan dalam suatu diagram seperti pada gambar 1. Pada gambar tersebut dapat dilihat keterkaitan baik antara variable endogen dan eksogen yang mempresentasikan fenomena ekonomi komoditas kedelai di Jawa Timur. 
Gambar 1. Hubungan antar variabel indogen dan eksogen

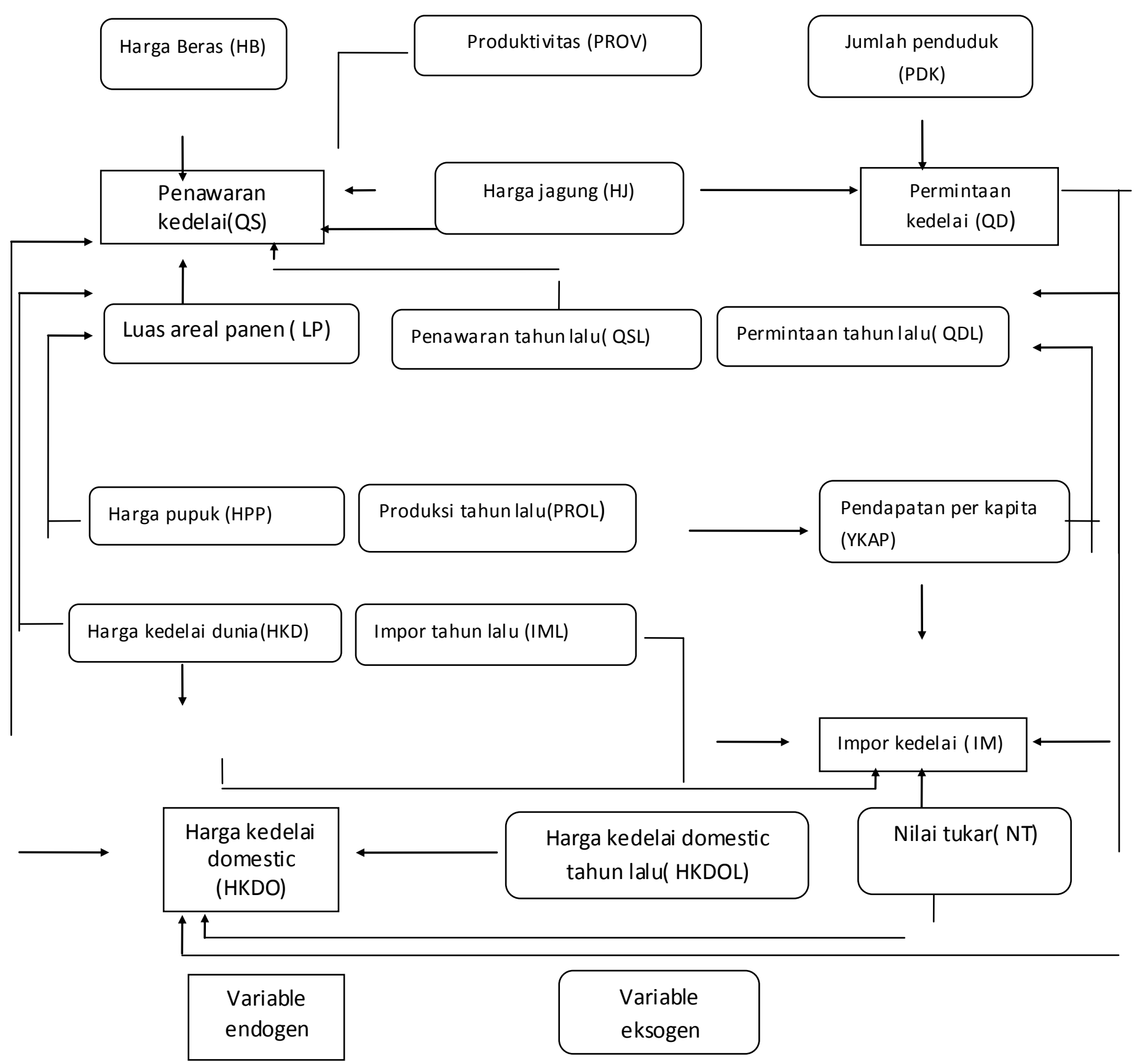


Harga kedelai domestic merupakan sentral dari perilaku penawaran, permintaan maupun perilaku impor. Pada satu sisi ,harga domestic memiliki keterkaitan negative dengan penawaran kedelai, sebaliknya penawaran memiliki keterkaitan positif terhadap penawaran, meskipun tidak begitu nyata sebaliknya, harga domestic memiliki keterkaitan positif terhadap permintaan meskipun tidak nyata. Sementara keterkaitan permintaan terhadap harga domestic bersifat negative. Keterkaitan impor terhadap permintaan bersifat positif, peningkatan permintaan meningkatkan impor.

\section{KESIMPULAN}

Berdasarkan hasil penelitian maka dapat ditarik beberapa kesimpulan penting dalam penelitian ini sebagai berikut: yaitu Metode penawaran dan permintaan domestic yang dibangun telah memenuhi criteria ekonomi, statistic dan ekonometrik dengan baik sehingga dapat digunakan untuk menjelaskan perilaku ekonomi komoditas kedelai di Jawa Timur dengan baik. Perilaku penawaran kedelai di pengaruhi secara positif oleh peubah harga jagung, produktivitas dan luas panen. Variable harga kedelai domestic, harga beras, harga pupuk dan harga kedelai domestic serta penawaran tahun yang lalu tidak berpengaruh terhadap penawaran kedelai.

Perilaku impor kedelai dipengaruhi secara positif oleh pendapatan per kapita dan permintaan tahun sekarang, dan dipengaruhi secara negative oleh produksi tahun lalu dan nilai tukar rupiah. Harga kedelai domestic dan peubah impor tahun yang lalu dinyatakan tidak berpengaruh terhadap impor. Perilaku permintaan kedelai dipengaruhi secara positif oleh jumlah penduduk dan di pengaruhi secara negative oleh pendapatan per kapita. Peubah harga kedelai domestic, harga jagung dan permintaan tahun yang lalu tidak memberikan pengaruh nyata terhadap permintaan kedelai. Harga kedelai domestic dipengaruhi secara nyata dan positf oleh penawaran dan nilai tukar rupiah tehadap US dollar serta harga kedelai domestic tahun yang lalu. Variable permintaan dan harga kedelai domestic tidak berpengaruh nyata terhadap perilaku harga 


\section{DAFTAR PUSTAKA}

Amang, Beddu. 1997. Ekonomi Indonesia. Penerbit Institute Pertanian Bogor

Andyana, Made. Oka nan Manwan, T. Ibrahim. 1999. Kebijakan dan Strategi Pembangunan Pertanian di Bidang Pangan Dalam PJP-II . Pusat Penelitian Dan Pengembangan Tanaman Pangan.

Bulog, 1999. Pasar dan Perdagangan Komoditas Kedelai di Sampaikan pada Seminar "Prospek Dan Presfektif Kedelai Di Jakarta".

Center For Agricultural And Rutal Develovment ( Card), Lowa State University 1988. "Analysis and Formulation of Food Crop Polity For Indonesia". Staff Report 90- Sr 48.

Gujarati. D.N. 1995. Basic Economics. London: Mc Graw-Hill Internasional Book Company.

Intriligator, M.D. 1978. Economitric Model: Techniques and Application. New Delhi: Prentice Hall.

Kasyno, Faisal .1998. Perubahan Pola Konsumsi . Permintaan dan Penawaran Produk Palawija . Pusat Penelitian Agro Ekonomi.

Koutsoyiannis. A. 1982. Modern Microeconomics. London: The Mac Millan Press Ltd

Rukmana, Rahmat. 1997. Kedelai Budidaya Dan Pasca Panen. Yogyakarta: Penerbit Kanisius.

Salvatore, D. 1989. Ekonomi Internasional. Jakarta: Gelora Aksara.

Samuelson, P. A. Dan Nordhaus, W.D. 1997. Mikro Ekonomi, Jakarta: Erlangga.

Sudarsono. 1995. Pengantar Ekonomi Mikro. Jakarta: Penerbit P.T. Pustaka LP3ES. 